\title{
A LIBERDADE DE EXPRESSÃO NA ROMA IMPERIAL.
}

"res olim dissociabiles miscuerit, Principatum et Libertatem" (Tácito, Agricola, III, 1).

\author{
SALVATORE D'ONOFRIO \\ da Faculdade de Filosofia, Ciência e Letras de Marilia \\ (São Paulo).
}

Os idos de março representam na história de Roma uma data importantíssima. O assassínio de César, perpetrado aos 15 de março de 44 a. C. por M. Júnio Bruto, C. Cássio Longino e mais uns sessenta senadores, foi um fato que abalou a consciência romana da época e ainda hoje se torna objeto de discussão entre os historiadores, que procuram analisar os motivos, a conveniência e os efeitos do crime.

Dada a personalidade do chefe da conspiração, não há dúvida que, pelo menos Bruto, foi levado a praticar o ato execrável por motivos muito nobres. Descendente do primeiro Bruto, aquêle que expulsou o último rei de Roma e inaugurou a feliz éra da República romana, sobrinho e genro de Catão Uticence, M. Júnio Bruto já tinha dado mais do seu apêgo aos ideais republicanos defendendo o Senado contra César e lutando em Fársalo ao lado de Pompeu.

Mas César, por sua magnanimidade, além de perdoá-lo, tinhalhe conferido o govêrno da Gália Cisalpina e a pretura urbana, querendo-lhe bem como a um filho. Assim, quando Cássio começou a reunir o grupo de conspiradores, a maior dificuldade que enfrentou para atrair Bruto foi o sentimento de gratidão que ligava Bruto a César.

Com uma argumentação muito sútil, Cássio convenceu-o de que o bem particular deve ser subordinado ao da pátria e que um tirano, mesmo sendo bondoso, não deixa de ser um liberticida. Diz-se que Bruto aceitou chefiar a conspiração, quando lhe lembraram esta expressiva frase de Cícero: 


\begin{abstract}
"libertas non in eo est ut iusto utamur domino, sed ut nullo" (o homem é livre não quando tem um dono justo, mas quando não tem dono nenhum) (1).
\end{abstract}

A idéia inspiradora que motivou o cesaricídio era nobre em si, pois visava salvar as instituições republicanas, que tinham feito de Roma a caput mundi e que agora estavam ameaçadas pelo complexo de podêres detido por César como Dictador perpetuus, título êsse que lhe conferia podêres absolutos e numa forma duradoura.

Bruto previu os males que o absolutismo teria acarretado à República, mas lhe faltou a visão histórica da realidade contingente. Não percebeu que as instituições republicanas estavam condenadas a desabar por causa das sucessivas guerras civis. A liberdade desaguava na libertinagem, os assaltos e escaramuças sucediam-se em ritmo sempre crescente, os Catilinas e os Clódios, na sua luta contra a aristocracia, lançavam mão de meios demagógicos e ilegais, tornando-se um perigo constante para a segurança nacional e individual; em suma, reinava não mais a fôrça do direito, mas o direito da fôrça, e a maior flor dos cidadãos romanos caía sob o punhal traiçoeiro. Este status quo não podia continuar; precisava-se urgentemente de um govêrno forte capaz de restabelecer a ordem interna do país, para poder, em seguida, resolver os graves problemas que afligiam a nação.

César, de uma clarividência política impressionante, sentiu a crise institucional e percebeu a causa principal da mesma: o obsoletismo do velho regime oligárquico e a necessidade de um Princeps, como elemento catalisador de tôdas as fôrças espirituais e materiais dos romanos. Sobrepondo-se ao Senado, constițuído de decrépitos conservadores, incapazes de entenderem a nova ordem das coisas, César se apoiou nas fôrças populares. De uma coerência única na época, êle foi sempre fiel à linha democrática, que tivera nos Gracos e em Mário seus melhores defensores.

A reforma política e social, de que a República precisava, foi iniciada por César desde seu primeiro consulado em 59 a. C.: promulgou a Lex Iulia agraria para acabar com o latifúndio, velha praga da economia agrícola italiana, dividindo o ager publicus entre os veteranos e os mais pobres; com a Lex Iulia municipalis visou a equiparação e a fusão dos cidadãos romanos e províncias da Itália, acabando com o velho privilégio do ciuis romanus sum e enriquecendo o Senado e outros altos cargos políticos com elementos novos das várias regiões da Itália e das Colônias; favoreceu o elemento militar, enquanto expressão mais viva da gens italica, e deu-lhe cargos públicos em substituição aos burocratas improdutivos.

(1). - Cfr. Paribeni (Roberto), L'Etá di Cesare e di Augusto. Bologna, Capelll, 1950, pág. 210. 
Estas e outras sábias disposições, que visavam a centralização do poder e a utilização de fôrças novas, foram frustradas pela conspiração de um grupo de fanáticos tradicionalistas, que, de olhos fechados à realidade do momento histórico, tentaram conservar um regime político obsoleto.

Afirma um eminente crítico (2) que, com o assassínio de César, a história de Roma sofreu um atraso de dois séculos, pois retardou a transformação que César tinha iniciado e que mais tarde se realizaria pela fôrça inelutável das coisas. Mas nós opinamos que em momento algum, na história da Roma imperial, se efetuou plenamente o sonho político-social de César. E' verdade que, depois de trinta anos de guerras civis, desordens, assassínios, traições e proscrições, se chegou com Augusto à almejada Pax romana, cimentada na autoridade do Princeps; mas tudo isso foi construído sôbre bases diferentes daquelas desejadas por César.

Augusto, certamente com mais espírito de oportunismo e de diplomacia, na sua ascensão ao poder se apoiou sôbre as velhas fôrças oligárquicas, respeitando o Senado (ou, melhor, fingindo respeitá-lo) e chamando os aristocratas a colaborar no seu govêrno. E' oportuno, a êste propósito, traduzir um trecho de Gaston Boissier:

\footnotetext{
"Embora Augusto devesse tudo a César, êle fazia questão de não ser cesariano. Parecia-lhe, sem dúvida, que, condenando ao mesmo tempo os vencedores e os vencidos, colocava seu poder acima dos partidos e fora das revoltas. Ele se tornara revolucionário para alcançar o Império, mas depois voltou a ser conservador para assegurá-lo: esta é a tática ordinária dos ambiciosos" (3).
}

Portanto, se do ponto de vista institucional houve uma reforma (a passagem da República para o Principado), as diretrizes políticas e sociais ficaram as mesmas, conservando-se o status quo, em que uma maioria de aristocratas se enriquecia com os cargos públicos e a grande massa do povo precisava contentar-se do panem et circenses. A um despotismo democrático, baseado nas correntes populares, idealizado por César, se substituiu um govêrno absolutista, apoiado no conservadorismo da oligarquia romana. Em linguagem moderna, poderíamos dizer que a frustrada revolução cesariana de esquerda cedeu o lugar à revolução augustina de direita. Mais uma vez recorremos ao pensamento de Boissier:

"César era, sem dúvida, o favorito e o defensor da democracia romana. Êle se achava, com muito gôsto, o continuador dos Gracos... Se tivesse tido tempo de fundar um govêrno sólido, é pro-

(2). - Paratore (Ettore), Storia della Letteratura Latina. Firenze, Sansoni, 1959, pág. 263.

(3). - L'Opposition sous les Césars. Paris, Hachette, 1875, pág. 294. 
vável que o teria apoiado nos votos e nas simpatias populares; mas o seu esperto sobrinho, que foi o verdadeiro fundador do Império, seguiu um sistema diferente. Ele preferiu o conúbio com a aristocracia e pretendeu continuar a política dela" (4).

A mudança institucional de Augusto teve êxito porque se alicerçou nas fôrças conservadoras das duas classes dominantes, senadores e cavaleiros, enquanto o proletariado romano logo se resignava à perda dos direitos políticos, passando a viver da esmola do poder público. Rostovtzeff (5) afirma que cêrca de duzentos mil proletários eram mantidos pelo Estado, recebendo uma ração de alimentos.

Augusto, como Princeps do Senado e Imperator do exército, estava apto a realizar um grande govêrno. $E$ o sobrinho de César não se demonstrou inferior às expectativas, sabendo muito bem aproveitar as condições favoráveis. Fechou o templo de Jano, em 29 a. C., e começou um govêrno de paz e de ordem. Reorganizou as Províncias e as finanças, construiu estradas para ligar entre si as regiões mais distantes, cuidou da edificação de monumentos, fêz várias reformas que visavam a revalorização da Família e da Religião, procurou pôr um freio aos maus costumes, incentivou a agricultura, etc.

Mas a obra maior de Augusto foi a justificação que procurou dar ao seu poder quase ilimitado, fomentando o surgir da ideologia do Principado. Continuou e deu forma concreta ao processo de deificação do princeps, começado por César, indo buscar na epopéia homérica o herói mítico, para demonstrar a origem divina da família Júlia. E' sintomático constatar que todo o homem que chega ao poder supremo através da fôrça ou de uma outra forma ilegítima, procura justificar essa sua posição envolvendo-se numa auréola de transcendentalidade. Julga-se o "predestinado", cuja ascensão ao poder não é devida a um jôgo de fôrças político-militares ou a uma qualquer outra contingência histórica, mas ao Fatum, ao destino, ao desígnio de Deus ou a uma superioridade individual ou racial. Exemplo típico, na história moderna, é Hitler e o fenômeno do Nazi-fascismo, que se atribuíram o direito de governar outros povos, fundamentados na filosofia nietzschiana do super-homem e da super-nação.

Mas, para que uma tal ideologia tome corpo e se difunda no meio da sociedade, é preciso que haja poetas, escritores, filósofos e artistas, que cantem as glórias do "carismático", demonstrando a sua origem divina. E Augusto, muito vivo, por intermédio do seu braçoforte Mecenas, não poupou dinheiro para que os melhores gênios da época entrassem na sua órbita e divulgassem o mito da descendência divina da casa Júlia.

(4). - O. c., pág. 63.

(5). - Historia de Roma. Rio, Zahar, 1961, pág. 177. 
Certo é que a primeira fase da época de Augusto salienta um conúbio admirável entre eventos políticos e produção literária. Ao programa de reconstrução política, social e moral de Augusto está ligado o máximo fulgor da Literatura Latina. E é difícil dizer se foi o Príncipe beneficiado pelas influências da produção literária contemporânea no planejamento de sua política, ou se foram os literatos a sentirem-se inspirados pelas reformas augustinas. Evidentemente houve uma troca de influências.

Isso quer dizer que a constante histórica das relações entre problemas sociais e literários, que determina fenômenos de interferèncias, visíveis na interpretação gestáltica de um determinado período de uma civilização, deu-se também na Literatura Latina, como se dera na grega e como se dará em tôdas as literaturas ocidentais. O ilustre crítico Otto Maria Carpeaux defende com unhas e dentes essa ligação entre História e Literatura, quando afirma:

"a relação entre literatura e sociedade não é mera dependência: é uma relação complicada, de dependência recíproca e interdependência dos fatôres espirituais (ideológicos e estilísticos) e dos fatôres materiais (estrutura social e econômica)" (6);

só que - inacreditàvelmente - abre uma exceção para as literaturas da antigüidade greco-romana, que considera

$$
\text { "exóticas, fora do ciclo da nossa civilização" (7). }
$$

Nega completamente qualquer relação entre fator social e produção literária, especialmente no que diz respeito à Literatura Latina. Vale a pena transcrever uns excertos:

\footnotetext{
"entre a literatura romana, imitação de uma literatura estrangeira por parte de uma elite culta, e as instituições romanas, obra original da nação, há um abismo. Por fôrça das suas origens e da sua própria existência, a literatura romana constitui o modêlo de uma literatura de elite, literatura intencional, artística, de evasão... A separação entre os escritores romanos e a realidade romana tem contaminado a nossa própria civilização inteira... devia ser literatura de evasão, porque não tinha nada com a realidade no meio da qual surgiu... A realidade espiritual, importada de fora, é uma planta exótica em Roma; os que pretendem viver nela, só podem fazê-lo como um alto funcionário que nas horas de ócio se entrega a caprichos de diletante, ou como um boêmio que se afasta das ocupações sérias da vida... e os representantes romanos do espírito defenderam a sua independência contra essa realidade material..." (8).
}

(6). - História da Literatura Ocidental. Rio, O Cruzeiro, 1959, vol. I, pág. 46.

(7) . - Idem, ibidem, vol. I, pág. 48.

(8). - Ibid., pág. 108-109. 
Sem querer entrar em polêmica com o emérito erudito, de quem sempre admiramos e invejamos a vastidão da cultura, a inteligência viva e os dotes singulares de perspicácia crítica, postos brilhantemente ao serviço da política, da sociologia, da literatura e da arte, queríamos perguntar-lhe se o poema de Lucrécio, os comentários de César, as orações de Cícero, a lírica de Virgílio, as obras de Horácio, as histórias de Tito Lívio, as sátiras de Juvenal, a produção tôda de Tácito e mais e mais obras literárias da romanidade são frutos de literatos "imitadores", "evasionistas", "exóticos", "ociosos", "diletantes", "boêmios" ou "individualistas", que viviam, êles todos, no sonho ou no ar, sem nenhuma ligação com o momento histórico em que cada qual estava vivendo!

Nada de mais falso e tendencioso, pois nenhuma literatura foi jamais tão engagée, tão atenta, preocupada e ligada ao fato social, quanto a latina, e isso pelo próprio espírito romano, eminentemente prático e utilitário. Em confirmação de quanto estamos afirmando, apraz-nos traduzir um trecho do exímio latinista Rostagni, que, explicando a literatura do período de transição da República para o Principado, ressalta:

"Também aqui, como para os paríodos do anterior desenvolvimento, nada pode ser tão útil como ter presente as conexões com as condições políticas e sociais, a que a literatura de Roma, mais do que qualquer outra ( o grifo é nosso), é constantemente ligada, a ponto de atingir delas as razões e os modos de vida" (9).

E essa é a opinião de todos os estudiosos da história e da literatura latina por nós consultados. Evidentemente, na introduçãa à História da Literatura Ocidental de Otto Maria Carpeaux, mais uma vez se verifica o constante preconceito dos autores do norte da Europa contra a latinidade; preconceito devido, talvez, à incapacidade étnica de penetrar no âmago mais profundo do espírito romano, para "sentitir", ainda agora, a vivência da sua civilização no mundo ocidental.

Mas, prosseguindo o nosso despretencioso ensaio, dizíamos que houve uma interdepedência profunda entre o programa de restauração do mos maiorum proclamado pelo Imperador Augusto e a produção literária da época. Até que ponto a autoridade do Impsrator Caesar Diui Filius e dos seus sucessores influenciou os escritores da época imperial será objeto de nosso estudo.

Podemos dividir a literatura latina da época de Augusto em duas fases, cada qual dotada de características bem diferenciadas. A primeira vai, aproximadamente, de 31 a. C. (vitória de Ácio) a (9). - Storia della Letteratura Latina. Torino, Unione Tipografica-Torinese, vol.
II, pág. 1. 
8 a. C. (morte de Horácio e de Mecenas); a segunda, de 8 a. C. a 14 d. C. (morte de Augusto).

A primeira parte da idade augustina representa o maior fulgor de tôda a literatura romana e denuncia o conúbio entre a produção poética e a realidade político-social, pois a literatura espelha e promove aquela maravilhosa entidade espiritual que foi o Principado de Augusto.

Os poetas e os escritores, como o povo em geral, estavam cansados das intermináveis lutas intestinas, e também os mais ferrenhos defensores da liberdade aceitaram o Principado de Augusto, cujo programa era de paz e de reconstrução social, pois a liberdade, a esta altura, era sinônimo de paz:

"A liberdade acabou de lutar e acabou de ser, pois se tornara paz" (10).

Mecenas, de família nobre e íntimo amigo de Augusto, se encarrega de ser o intermediário entre os maiores gênios da época e o Imperador. Para criar a atmosfera favorável ao Principado, êle vai convidando no seu círculo os autores romanos mais capacitados, não se preocupando com o seu credo político. Assim, atenderam ao chamado de Mecenas, Virgílio, ferrenho cesariano; Horácio, republicano e epicurista; Propércio, de família republicana; e mais uma teoria de poetas menores de conviç̧ões políticas as mais diferentes. A todos Mecenas procurou atrair para a esfera política e espiritual do Principado de Augusto. E conseguiu de alguns perfeita adesão à nova ideologia, seja pelo clima de paz, de tranquiilidade e de grandiosidade instaurado pela reforma de Otaviano, seja pela ajuda e confôrto material proporcionado aos cultores das Musas.

O "mecenatismo" se tornava uma necessidade, visto que aquêles que se dedicavam à cultura não recebiam nenhuma ajuda por parte do Estado. Sòmente quem tivesse condições econômicas favoráveis podia dedicar-se ao otium literário, restringindo-se, assim, o cultivo das letras, da filosofia e das artes a uma minoria privilegiada. Esta triste situação não era, porém, peculiar ao mundo romano. $\mathrm{O}$ problema do custeio da educação púbîica sòmente foi resolvido na éra moderna, e não ainda perfeita e universalmente. Guillemin não pensa diferentemente:

"os escritores antigos enfrentaram dificuldades que não desapareceram antes do sécculo XIX" (11);

(10). - Marchesi (Concetto), Storia della Letteratura Latina. Milano, Principato, 1959, vol. I, pág. 380 .

(11). - Le Public et la vie littéraire a Rome. Paris, Les Belles Lettres, 1937, pág. 95. 
quando se difundiram as escolas públicas, tomou corpo a classe dos professôres pagos pelo Estado e a difusão da imprensa barateou os livros, que, adquiridos por uma grande quantidade de pessoas, podiam proporcionar a seus autores meios de subsistência autônomos.

No passado, entretanto, precisava-se de ricos "protetores", que libertassem os escritores das dificuldades econômicas, pois o provérbio carmina non dant panem se tornava um problema de outra forma insolúvel. Foi por isso que, quando se começou a perceber a enorme importância da cultura na formação da sociedade, os aristocratas romanos abriram suas portas aos intelectuais e se formaram os chamados "círculos literários". Cipião deu o exemplo, seguido mais tarde por Mecenas, Messala Corvino e Asínio Polião. O mais famoso foi, sem dúvida, o círculo literário de Mecenas, cujo fundador passou à história como protótipo de amparador dos homens da cultura.

$\mathrm{Na}$ época de Augusto, pelo menos na primeira fase, a generosidade do Príncipe e de Mecenas parece não ter tolhido a liberdade de expressão aos poetas. Era uma generosidade que não ofendia e não impunha condições de sujeição e de escravidão espiritual. A ligação era fundada mais sôbre o conceito epicurista da amizade do que sôbre o da autoridade.

A passagem do Virgílio "bucólico" - o homem que, desgostoso pela experiência das brutais lutas políticas, chega a uma concepção negativa da vida social, em que reina a injustiça, o arbítrio e o sofrimento, e que encontra na natureza a única possibilidade de vida feliz - para o Virgílio "épico" é devida mais às mudadas condições político-sociais do que ao favoritismo de Augusto e de Mecenas. Escreve o maravilhoso canto épico no momento em que recomeça a acreditar na bondade dos homens e no grandioso destino de Roma. A Eneida, na realidade, não é tanto o canto do herói mítico Enéias, nem a glorificação de Augusto ou da família Júlia, mas, antes de mais nada, a exaltação do espírito eterno de Roma, vista como fôrça propulsora da civilização humana. Nada de servilismo adulatório, então, mas profundo espírito patriótico.

Alguns críticos querem ver também em Horácio a mesma evolução espiritual: o Horácio crítico, epicurista, cínico e sarcástico dos Epodos e das Sátiras, depois de sentir a atuação benéfica do Principado de Augusto, teria evoluído para o Horácio do lirismo patriótico em louvor do Imperador. Mas suas Odes Romanas e, de modo particular, o Carmen saeculare são mais a exaltação da Roma antiga do que a glorificação do govêrno de Augusto. Não queremos entrar no discutido problema da sinceridade e da autenticidade 
do sentimento cívico de Horácio. Para isso enviamos os interessados ao trabalho cuidadoso de Antônio La Penna (12).

Certo é que custa muito acreditar numa conversão política de Horácio. O antigo militante do exército de Bruto, o defensor das idéias republicanas, o culto e refinado tradicionalista não podia, de um dia para outro, tornar-se o cantor de um regime que, sob as aparências de uma larvada democracia, era uma quase monarquia. Sílvia Iannaccone é da mesma opinião quando afirma:

"O ânimo do poeta, não propenso a quanto se ia realizando na linha cesariana, embora se tivesse conciliado com a nova ordem das coisas, nunca aplaudiu a obra de Augusto, mesmo quando pareceu secundar o desêjo do Imperador de exaltar a obra imperial" (13).

E que Horácio nunca morreu de amôres por Augusto demonstra a sua firme recusa ao convite do Imperador, que o queria como secretário particular (14), e a desculpa de falsa modéstia, quando convidado a cantar as façanhas do Princeps (Sat. II, 1, 10-20).

Cabe aqui dizer que Augusto nunca impôs condições aos poetas, nem exigiu louvores desmedidos. Deixou quase sempre que cada um cultivasse o gênero literário que mais the aprouvesse, e que fôsse livre para expressar idéias e sentimentos na forma mais pessoal. Se é : verdade que Augusto fazia questão do apôio dos escritores para a realização do seu plano de govêrno - e disso é prova a insistência com a qual êle pede a Virgílio o acabamento da Eneida para que, junto com o Carmen Saeculare de Horácio, inaugure os jogos seculares do ano 17 a. C. - não podemos negar, porém, que tal apôio é solicitado de uma forma amigável, e não exigido ou impôsto. E' o amigo benfeitor que pede a exaltação da obra que está realizando e não o tirano que escraviza a livre expressão da classe culta.

Apesar de tudo isso, uma certa limitaç̃̃o de liberdade existia e, mesmo não imposta por Augusto, se encontrava na atmosfera criada pelo nôvo regime político. A pax augustina e a reforma institucional, que tirava ao povo romano a possibilidade de, através do voto, escolher os próprios representantes, levou ao enfraquecimento das paixões políticas. Se isto favoreceu grandemente a instauração do regime imperial, de outro lado afastou os grandes gênios da vida pública.

E' sintomático o fato de que, enquanto na época republicana os maiores expoentes da literatura eram também os mais importantes homens do Estado (e. g., Cícero e César), na época imperial os li-

(12). - Orazio e l'ideologia del Principato. Torino, Einaudi, 1963.

(13). - Il segreto di Orazio., em Giornale Italiano di Filologia, n॰ 4, $1960,290$.

(14). - Marchesi, o. c., I, pág. 473. 
teratos permanecem à margem da vida pública e se dedicam sòmente ao otium literário. O fato é claramente explicável: em qualquer regime democrático os políticos precisam do cultivo das Letras para poder, com a erudição e a eloquiência, conquistar o favor do público, cujos votos são indispensáveis aos fins da carreira política. $O$ que não se dá num regime absoluto, onde os chefes da Nação são escolhidos ou por direito de herança, ou por protecionismo do antecessor, ou por um golpe militar.

Por êste motivo, o primeiro e mais importante gênero literário latino que decai completamente na época imperial é a arte da Oratória. A grande eloqüência política acaba com Cícero, assassinado vergonhosamente por Antônio com a conivência do mesmo Otaviano. E (pudera!) para quê eloqüência política, se não existiam mais os Catilinas, os Clódios e os Antônios, contra os quais defender as instituições republicanas? E como se podia exercer a função de orador, quando a República mesma não existia mais?

Assim, a verdadeira eloqüência, perdida a sua razão de ser, se tornou um estéril exercício de declamação, passando da praça pública para o fechado recinto das escolas. As Suasoriae tomaram o lugar da eloquiência política e as Controversiae substituíram a eloquiência judicial. As primeiras eram compostas de monólogos imaginários de heróis mitológicos ou históricos que dissertavam sôbre os motivos pró e contra, antes de tomarem uma grave decisão; nas segundas eram chamados dois declamadores, cada qual obrigado a defender o seu ponto de vista sôbre uma determinada questão. Verdadeira retórica, enfim, sem nenhuma utilidade prática, atulhada de lugares comuns acêrca dos conceitos de "liberdade", de "virtude", de "justiça", etc. A coisa mais deletéria foi que estas recitationes empestaram tôda a literatura imperial, pois

"o caruncho do artifício retórico, uma vez entrado no sistema, se propaga: cria uma espécie de hábito mental, que, no lugar de encontrar resistência ou correção, é secundado pela moda, e impregna de si todo estudo, tôda forma de prosa e de poesia" (15).

$E^{\prime}$ interessante notar como o primeiro grande retor da época imperial, o espanhol (16) L. Aneu Sêneca, que dedicou a maior parte de sua vida a êstes exercícios de declamação, manifesta no prefácio ao último livro das Controversiae uma sorte de enjôo e de vergonha por ter perdido seu tempo com tais bobagens.

(15). - Rostagni, o. c., vol. II, pág. 305.

(16). - No comêço do primeiro século da éra cristá, uma plêiade de escritores e poetas vieram da Espanha, entăo Colônia romana, e enriqueceram a $\mathrm{L}$ teratura Latina. Mas a peculiaridade do estilo dêles introduziu nas Letras de Roma uma veia de pomposidade, de afetação, de sutlleza, em suma, de um "barroco" antes do tempo, que favoreceu muito a difusăo da arte declamatória. Peculiaridade já notada por Cícero, quando ressaltava no estilo dos espanhóis "pingue quoddam et peregrinum": Pro Arch., X, 26. 
O problema mais grave ainda é que a crise da eloqüência não é um fato isolado, mas se alastra a tôda a produção em prosa. Se o primeiro momento do Principado de Augusto foi benéfico para a poesia em geral, o mesmo não se pode dizer para a prosa. Parece que o pensamento reflexo se afrouxa por falta dos esímulos fecundos do debate político. O único grande escritor em prosa da época de Augusto é o historiador Tito Lívio. Mas suas Histórias têm muito pouco de análise fria e objetiva dos fatos acontecidos; são mais uma exaltação das glórias de Roma de suas origens até o fim da República. Antes do que história, é poesia em prosa, visando exaltar o passado glorioso do Senado e do povo románo; passado sentido como saudade de um tempo maravilhoso, que acaba com o fim da República.

Percebe-se que a Literatura Latina, no momento mesmo de seu maior esplendor, denota aquêles sinais de crise e de decadência que serão bem visíveis mais tarde, nos sucessivos séculos de Roma imperial. Rostagni acredita ver dois sintomas de decadência na crise da prosa e no afastamento da literatura das correntes vivas do povo:

\footnotetext{
"Geralmente, no momento mesmo em que chegava às formas mais pujantes, a literatura estava para emurchecer: de um lado perdia dentro de si o sustento, a razão, a propulsão do pensamento; de outro lado abandonava o antigo vivo contacto com as correntes do povo, com as mais amplas camadas da sociedade e com os interêsses mais verdadeiros da vida" (17).
}

Podemos apontar uma outra causa: o fenômeno da "aculturação" ,determinado pelo rápido progresso do cosmopolitismo, que fazia chegar a Roma gente de tôdas as províncias, cada qual introduzindo usos e costumes novos, e que vinham deteriorar os dotes de equilíbrio e de gravidade, característicos nacionais do espírito e da cultura romana. Sem querer renegar os influxos benéficos do Helınnismo, é de se salientar, porém, que a influência da civilização oriental - e grega em particular — sôbre os costumes romanos foi deletéria: não foi por nada que a maioria dos escritores da época imperial se lançaram contra ela. O fracasso do plano restaurador de Augusto, especialmente no que diz respeito ao restabelecimento do mos maiorum, se deve em grande parte a êste cosmopolitismo, em que se afogavam os princípios da virtus e da pietas romana pela introdução no mundo latino de uma moral mais complacente e de cultos religiosos exóticos e, às vêzes, obscenos .

Essas causas, tôdas elas e além de outras, concorreram para a deterioração do espírito romano e preparavam a decadência política, social e literária. Mas, se quisermos encontrar a causa das causas,

(17) . - o. c., vol. II, pág. 22. 
devemos procurá-la, a nosso ver, no hibridismo do regime instaurado por Augusto. O Principado surgiu baseado num assentamento equívoco: o chefe do Estado jurava respeitar a tradição republicana $\mathrm{e}$, ao mesmo tempo, governava como um déspota. A grande personalidade de Augusto conseguiu superar êsse dissídio, amalgamando, de uma certa forma, tôdas as fôrças ao redor do Princeps. Mas, com os seus sucessores, a contradiçáa se manifestou claramente, gerando uma série de problemas de tôda ordem.

O povo é afastado cada vez mais da vida política. O imperador Tibério transfere a nomeação dos magistrados ao Senado, e o povo, além de năo reclamar, aceita a coisa como uma obrigaçào a menos. Em efeito, depois de César, o povo romano perde a consciência de sua fôrça política, só reclamando quando a distribuição de trigo é escassa ou os jogos do circo são raros. O Senado, também, perdia o prestígio cada vez mais. Era obrigado, quisesse ou não, a aceitar tôdas as determinações do Imperador. Exercia o triste papel de adulador diante de todos, mas conspirava à socapa .

O pior de tudo, porém, era que o mesmo Imperador não gozava de uma posição confortável. Enquanto tinha plenos podêres, era obrigado a respeitar, pelo menos formalmente, a tradiçâo republicana. Podia mandar como um monarca, mas não tinha investidura para tal. Nero tinha razão de dizer que seus predecessores não sabiam exatamente o que lhes era permitido fazer. E isso porque o poder desmedido, de que o Imperador usufruia, não lhe provinha nem de um direito dinástico, nem de uma consagração popular: era ilegítimo. Daí a insegurança, a falta de serenidade, as suspeitas, o mêdo de tramas e de conspirações. E nada torna ninguém tão feroz como o mêdo:

"É assim que os súditos e o Imperador, objetos de assombro uns dos outros, viviam entre si num estado de desconfiança mútua e de mêdo recíproco. Daí as desgraças que afligiram Roma durante séculos. Um tal poder soberano, que não era seguro de si mesmo e se amedrontava fàcilmente, tornava-se inevitàvelmente cruel, porque não há nada que torna ninguém tão feroz como o mêdo" (18).

A crueldade começa nos últimos anos do Principado de Augusto e se alastra por tôda a época imperial. Poetas e escritores, que não compartilham as idéias e os planos do govêrno, estão sujeitos aos castigos mais variados, instaurando-se assim, pela primeira vez em Roma, um verdadeiro terror cultural.

A primeira vítima da intolerância de Augusto é o historiador grego Timagenęs, expulso do palácio imperial por ter ousado pala-

(18). - Boissier, o. c., pág. 69 . 
vras desrespeitosas contra a família do Imperador. Asínio Polí, que ostentava a máxima complacência com os adeptos das idéias republicanas, logo o aceita na sua casa. Sêneca, o filósofo, diz que Timagenes era disputado por todos os cultos aristocratas só pelo fato de ter sido expulso da casa de Augusto (De Ira, XXIII, 5). Daí se vê que, depois da morte de Mecenas, Horácio e Virgílio, o Imperador não goza mais de muita estima nos círculos literários de Roma.

No ano 8 d. C. Augusto faz exilar o último grande poeta de Roma, Ovídio, despachando-o para o Ponto Euxino, de onde nunca mais voltará. As causas de uma tão grave decisão são ainda pouco claras. E' quase certo, porém, que Augusto não perdoou a Ovídio a intromissão na vida particular de sua família, como também a sua Ars Amatoria, em que o poeta falava com simpatia do adultério e do amor livre. Temos a impressão de que o Imperador quis vingar na pessoa de Ovídio o fracasso do seu programa de restauração moral da família romana. Mas era como querer tirar o efeito sem eliminar a causa: a corrupção da sociedade romana era um fato evidente. Na própria família de Augusto, as duas Júlias, filha e neta do Imperador, se tornaram o alvo predileto de falatórios na cidade pelos seus adultérios e escândalos, tanto que Augusto foi obrigado a exilá-las. Como falar de volta ao mos maiorum, se o maior amigo de Augusto, Mecenas, a quem coube o papel de reunir as vozes mais altas da Musa romana ao redor do Imperador em apôio à escalada da restauração dos costumes, era, êle mesmo, um refinado gozador da vida, amante do luxo e dos prazeres? Traduzimos Rostagni:

"Por êles (= fragmentos de versos de Mecenas) e por tudo aquilo que de precioso, de relaxado e de mórbido se percebe no complexo dos testemunhos e nas impressōes dos fatos, Mecenas aparece como mensageiro de uma decadência moral, que, no fundo, não pode ser senão decadência também intelectual e literária. Enfim, não foi justamente êle, Mecenas, que assumiu, de uma certa forma, a tarefa de adormecer as consciências para adaptá-las à nova ordem?" (19) .

Ovídio foi, portanto, um fiel espêlho da época e não um corruptor de costumes já corruptos. Daí a injustiça do duro castigo que the foi infligido.

Outras vítimas da perseguição literária de Augusto foram dois oradores, culpados de ter feito oposição ao regime imperial: Tito Labieno, cujos escritos foram queimados no ano $12 \mathrm{~d}$. C., e Cássio Severo, expulso de Roma, mais ou menos no mesmo ano (20). 
Com os sucessores de Augusto, as coisas vão piorando para os escritores. Ao mecenatismo se substitui o triste métier da clientela, e são poucos os literatos que conseguem escapar ao servilismo e à adulação. A literatura de oposição só se encontra em círculos fechados, em algumas escolas de declamação ou em pequenos grupos que se juntavam no Forum, no Campo de Marte: os politiqueiros, chamados de subrostrani (21).

Mas a difusão da vergonhosa turma dos delatores ou espiões torna inseguro o ambiente mais fechado. $\mathrm{O}$ mêdo dos delatores era tamanho que os oposicionistas tinham-se acostumado a se comunicar sem palavras, como afirma Tácito com uma expressão de grande efeito: occulta vox aut suspicax silentium (Annales, XIV, 50).

Tibério, através do seu famigerado ministro Sejano, se tornou autor de providências odiosas e cruéis em relação a vários escritores. Cremúcio Cordo, em 25 d. C., é obrigado a suicidar-se por ter expressado, em sua obra histórica, sentimentos favoráveis aos ideais republicanos. O mesmo acontece ao poeta e orador Mamerco Escauro, que teve a ousadia de, numa tragédia, escrever alguns versos contra a tirania. Acêrca dos dois traduzimos o historiador Suetônio:

\begin{abstract}
"As maiores recompensas foram dadas aos acusadores e, às vêzes, também às testemunhas. Todo mundo acredita nos espiões. Qualquer acusação se torna capital, embora se trate de poucas e simples palavras. Acusa-se um poeta (Mamerco Escauro) de ter, numa tragédia, injuriado Agamenão; igualmente se acusa um historiador (Cremúcio Cordo) de ter chamado Bruto e Cássio de "os últimos romanos"; êstes escritores são imediatamente executados e suas obras destruídas" (Tibério, LXI, 2-4).
\end{abstract}

Tácito não diz menos: nos Annales (IV, 34-35) descreve o processo de Cremúcio Cordo, em que tenta demonstrar como é iníquo e ridículo vexar, com a fôrça bruta, as obras do intelecto. Em 35 d. C., os escritores satíricos Hélio Saturnino e Séstio Paconiano são condenados por versos injuriosos à tirania: o primeiro é atirado do penhasco Tarpéia e o segundo é estrangulado na prisão (22).

Não menos intolerante para com os escritores foi o sucessor de Tibério, Calígula, que depois dos primeiros anos de uma certa lúcida benevolência, começou a ver rivais em todos os poetas. De seus excessos de criminosa loucura a duras penas conseguiu escapar Sêneca Pai. O declamador Carrina Segundo foi condenado ao exílio; um autor de Atelanas, por um simples verso de brincadeira com duplo sentido, foi queimado no anfiteatro; a um cavaleiro romano, por ter proclamado a sua inocência, mandou-lhe cortar a língua (23).

(21) . - Cfr. Bolssier, o. c., pág. 83

(22). - Cfr. Rostagni, o. c., pág. 242 (vol. II).

(23) . - Suetônio, Caligula, XXVII, 8-9. 
Não obstante êste terror cultural, a literatura de oposiç̃̃̃o ao despotismo nunca cessou de existir, embora numa forma tímida, dissimulada e ineficaz. Boissier (24) cita três veículos de oposição literária: os panfletos, distribuídos secretamente e lidos àvidamente; os epigramas anticesaristas; e a literatura de alusão, lida nas bibliotecas públicas e nos círculos de declamação, onde, exaltando os tiranicidas do passado, indiretamente se atiçava o ódio contra o déspota da época.

Esta literatura de oposição, que viveu na sombra por quase meio século, parece gozar de um período de maior tolerância sob os imperadores Cláudio (41-54) e Nero (54-68). Afetando veleidades literárias e artísticas, os ditos imperadores tentaram renovar o mecenatismo de Augusto, declarando-se protetores de poetas e escritores. Este clima de momentânea liberdade de seus frutos, pois

\footnotetext{
"vemos determinar-se uma vasta floração espiritual que tem quase sentido de renascimento e de reação em relação aos decênios precedentes, quando conspícuos vultos de escritores não sobressaíram ou ficaram confundidos no clima de incerteza, de torpor, de esterilidade" (25).
}

Grandes figuras de poetas e de escritores surgem nesta época, todos êles produtos dos germes de rebelião ao despotismo. A filosofia estóica desempenha um papel importante nesta renovação espiritual. O Estoicismo romano, de caráter meio eclético - não desdenhava, pois, elementos de outras doutrinas, mormente do epicurismo - e de feição religiosa, assumia a tarefa de guiar e de melhorar a humanidade, em face da prepotência política e da corrupção dos costumes. Sêneca Filho, o maior filósofo romano, depois de sofrer o exílio e vexações por parte de Messalina, recebe, no ano 49; a incumbência da educação de Nero, filho de Agripina, que, ascendendo ao poder em 54, escolhe-o como conselheiro e diretor da política imperial. O Império Romano gozou, então, de alguns anos de sábia administração e as letras pareciam ter encontrado a proteção de um nôvo Mecenas.

Mas esta ilusão durou pouco. Nero não tardou a manifestar a sua índole sanguinária e, impelido sem dúvida pelo mêdo, perpetrou os maiores crimes: o irmão Britânico, a mãe Agripina, a espôsa Otávia, entre outros, caíram vítimas de sua ferocidade. Sêneca, desgostado e desiludido pelo fracasso da sua obra de educador, sentindose meio culpado e comprometido, retirou-se para a vida privada, sendo mais tarde obrigado a matar-se.

(24) . 一 O. c., pág. 96 .

(25) . - Rostagni, o. c., pág. 340 (vol. II) . 
A participação do filósofo Sêneca no govêrno de Nero constitui um fato muito importante, pois denota a volta do interêsse dos literatos para a res publica, como antes do Império. A literatura se torna, outra vez, instrumento de luta, e seus cultores mergulham no clima afogueado das paixões políticas, exaltando-se no ódio contra a tirania e desafiando até a morte.

$E^{\prime}$ interessante notar, porém, como êste reflorescimento dos sentimentos patrióticos provém, não da aristocracia romana, já decrépita e dedicada sòmente aos prazeres, mas de fôrças virgens que vinham do Ocidente e, particularmente, da Espanha. Os Sênecas tinham criado, por assim dizer, uma escola de entusiasmo e de virtude em Roma, chamando a atenção dos romanos para o antigo heroísmo do povo latino. São os primeiros laudatores temporis acti, em face da aberração em que jazia a Roma contemporânea. Os outros maiores representantes da literatura desta época são ligados, quase todos, à família de Sêneca Filho e à corrente estóica: Lucano é seu sobrinho, Aneu Cornuto é seu liberto, Pérsio é discípulo dêste.

O único grande escritor verdadeiramente romano - de nascimento, de espírito e de educação - é Petrônio (26): mas êle é, também, o único literato da época que se alienou das lutas políticas. A sua obra Satiricon é fruto de um homem requintado, moderno, desabusado, que olha, cético e impassível, para o desenrolar dos eventos humanos e os descreve com ar de superioridade e de fino humorismo. E o humor

$$
\text { "nasce do desencanto irremediável da vida" (27). }
$$

Desencantamento: é a palavra exata para expressar o estado em que se encontra a sociedade tradicional romana depois de Augusto. Era preciso, então, que gente nova, vinda de fora, injetasse nova linfa nas artérias esclerosadas do povo de Roma. Surge, assim, pela primeira vez na época imperial, uma literatura eminentemente oposicionista. Sêneca, seja na obra filosófica, seja na sátira do Apokolokyntosis Diui Claudii ( = a "aboborificação" do divino Cláudio), seja nas tragédias, não se cansa de gritar contra a tirania. A Farsália de Lucano é uma polêmica feroz contra o Principado despótico de Nero em nome da tradição republicana. Pérsio - retomando o gênero satírico e imitando mais a sátira violenta de Lucílio do que aquêla serena de

(26) . - Cabe aqui uma ressalva sôbre a época de Petrônio. Năo obstante as argumentaçōes de Enzo V. Marmorale (Storia della Letteratura Latina Napoli, Loffredo, (1958), pág. 268-269), que pretende colocar Petrônlo depois do Imperador Cômodo, somos ainda da opinião tradicional que năo vê distinção entre o Petrônio autor do Satiricon e o Petrônjo arbiter elegantiae da côrte de Nero.

(27) . - Moog-(Vianna), Heróis da decadência. Rio, Civilizaçăo Bras., 1964, pág. 26. 
Horácio - descreve os vícios da sociedade romana, não sem veladas estocadas ao govêrno e pessoa de Nero.

Naturalmente esta oposição não passou impune: custou-lhes a vida. Sêneca e Lucano receberam do Imperador a ordem de morte; Pérsio evitou o castigo por ter morrido muito jovem. E Petrônio, o arbiter elegantiae da côrte de Nero, que, embora não adulador, nunca foi oposicionista, recebeu a mesma ordem de morte, por ter cometido o grave êrro de suscitar a inveja do ministro Tigelino (28).

A perseguição não atingiu sòmente os grandes escritores, mas também a humilde turma dos pregadores populares da filosofia cínico-estóica, cuja oposição tinha um significado mais moral do que político. A pregação cínico-estóica apontava para o retôrno à vida simples da natureza e à observância das regras mais comuns de honestidade: o motivo político, se existia, era implícito e oculto. A arma usada era a mais convincente: o exemplo. Sêneca afirma que os estóicos pediam a menor das liberdades, a de ficar calado: tacere liceat: nulla libertas minor a rege petitur (Oedip., 523). Mas nem isso, às vêzes, thes era concedido, pois só o exemplo de sua vida austera ofendia os corruptos cortesãos. Boissier, comentando um trecho de Tácito (Ann., XVI, 22: rigidi et tristes, quo tibi lasciviam exprobent), assim imagina um costumeiro encontro de Nero com um filósofo praticante:

"Quando Nero voltava para o seu palácio, trajado como um cocheiro ou como um comediante... êle, sem dúvida, se enfurecia se encontrava uma dessas pessoas de tez pálida, de porte grave, de trajo sério, que parecia achar-se em seu caminho para recordar-lhe seus deveres" (29).

A época imediatamente pọsterior, a da dinastia Flávia, não apresenta nada de melhor do ponto de vista da liberdade de expressão. A revolta da Gália obrigou Nero a suicidar-se e, em 68 , abriu-se uma crise política no govêrno de Roma. No espaço de um ano, nada menos que três imperadores (Galba, Otão e Vitélio) sucederam-se na direção do Império. Foi o exército do Oriente que impôs seu general, Vespasiano, e restabeleceu a ordem. Com a dinastia Flávia aumentou sensivelmente a autocracia, chegando-se à realização do sonho de vários imperadores, o de constituir em Roma uma monarquia de tipo oriental. Vespasiano (69-79) tornou o Império hereditário, tendo como sucessores seus dois filhos: Tito (79-81) e Domiciano (81-96). E o Imperador passou a ser chamado de dominus et deus.

Seguindo a já velha ambição imperial, todos êles são cultores das Letras e benfeitores de poetas e escritores. Vespasiano foi o pri-

(28) - Cfr. Tácito, Annales, XVI, 18-19.

(29) . - O. c., pág. 111. 
meiro a criar escolas públicas custeadas pelo Estado, e Quintiliano, o maior retor da época, foi chamado a tomar a direção de uma delas. Mas, ao mesmo tempo em que estas escolas difundem a cultura, elas são destinadas a dar o ganha-pão a uma fileira imensa de aduladores, de "clientes" e de escritores áulicos. Por isso não é de se estranhar se Quintiliano, homem de uma cultura fabulosa, chama Domiciano o maior dos poetas e o mais digno homem de Estado:

\footnotetext{
"o que existe de mais sublime, de mais acabado e de mais excelente sob todos os pontos do que estas obras a que êle (= Domiciano), desde môço e renunciando ao império em favor do pai e do irmão, se dedicara? E quem teria podido cantar as guerras melhor do que aquêle que tão bem as faz?" (30).
}

Um tão desmedido elogio, em si ridículo, se torna trágico nos lábios de uma pessoa cultíssima como Quintiliano!

Mas êle não foi o único: a maioria dos escritores e poetas desta época (Sílio Itálico, Valério Flaco, Estácio, Plínio o Velho, Marcial, etc.), qualquer que seja o gênero literário cultivado, procuram agradar ao Imperador, desenvolvendo uma literatura de imitação, sem originalidade e sem vigor, adulatória e servil. Quem tenta escapar a esta moda e expressar livremente as próprias idéias incorre, inexoràvelmente, na ira do déspota .

Domiciano foi o mais intransigente dos Flávios. Castigou, de modo particular, os cultores da filosofia estóica, que, através da livre discussão, da pregação popular, do espírito crítico, exprimiam uma certa oposição contra o govêrno despótico: Musônio Rufo, Helvídio Prisco, Herênio Senecião, Aruleno Rústico, Díon Crisóstomo, Epiteto, entre outros, sofreram penas das mais variadas e tiveram seus escritos queimados.

$$
\begin{aligned}
& \text { "A liberdade - tinha dito Sêneca - não pode ser alcançada de } \\
& \text { graça" (31). }
\end{aligned}
$$

Com a morte de Domiciano, Roma saiu do pesadêlo das perseguições e dos crimes, e a literatura pôde gozar de uma quase absoluta liberdade de expressão. Os imperadores da família Antonina (Nerva, 96-98; Trajano, 98-117; Adriano, 117-138) tiveram o grande mérito de se preocupar mais com a reorganização do Império do que com o patronato literário, deixando em paz poetas e escritores. Sem veleidades poéticas, como todos seus predecessores, os Antoninos nem protegeram, nem obstaculizaram o livre desenvolver-se das atividades literárias.

(30). - Inst. Or., X, 1, 91 .

(31). - Epist., 104, 34. 
Daí o surto, na literatura latina desta época, de belíssimas individualidades, quais Tácito, Juvenal e Plínio o Môço. Um grito de reação contra a passada tirania, um anélito de libertação, um sentimento de desagravo parece sair do peito de todos os escritores desta época. Rostagni (32) recolhe vários trechos de literatos que cantam o hosana para a reconquistada liberdade. Tácito:

“agora finalmente se volta a respirar... agora estão juntas duas coisas antes contraditórias: o Principado e a Liberdade... pela rara felicidade dos tempos é permitido pensar o que se deseja e expressar o que se pensa";

Plínio:

"durante o teu govêrno (= o de Trajano) retiveram fôlego, sangue e pátria os estudos, que antes a ferocidade dos tempos condenava ao exílio";

Floro:

"graças a Trajano o Império está retomando vigor e sua velhice parece, além de qualquer expectativa, rejuvenescer".

Juvenal parece associar-se ao côro destas vozes que louvam os áureos tempos da reconquistada liberdade, quando afirma: Et spes et ratio studiorum in Caesare tantum (Sat. VII, 1). Na realidade êle é um satírico revoltado contra a corrupção da época, não acreditando numa súbita melhoria da sociedade romana: os males vinham de longe e estavam tão arraigados que nenhum govêrno, mesmo excelente, podia extirpá-los de um dia para outro. Embora êle afirme que sua sátira é dirigida contra o passado (I, 170-171) - e, efetivamente, os ataques mais violentos são contra Nero e Domiciano - , não podemos negar que os assuntos de suas sátiras espelham também a sociedade contemporânea. Na Sátira primeira (vv. 85-86) êle diz que

\footnotetext{
"tudo o que os homens fazem, votos, temores, iras, prazeres, alegrias, erros, tudo será misturado no meu livro":
}

é claro que tudo isso diz respeito também a sua época. A verdade é que Juvenal tem mêdo. A sua sátira é muito violenta e êle teme as vinganças dos atacados. O acertado artifício literário da retrospecção serve-lhe, então, para pôr-se ao abrigo de possíveis represálias. Não acredita muito na momentânea liberdade de expressão e na tolerância da dinastia dos Antoninos. Juvenal desconfiava que as coisas podiam mudar ràpidamente, pois, na maioria dos casos, os imperadores romanos assumiam o poder com as melhores das intenções, mas, aos poucos, iam piorando, chegando aos extremos limites da violência.

(32). - O. c., vol. II, pág. 516-517. 
A falha estava não no Príncipe, mas no regime despótico, pois o Imperador, assumindo o poder pela violência, era obrigado a usar a violência para não ser destronado: vim vis gerat. Disso - melhor do que Juvenal - se apercebeu o grande historiador Tácito. Em tôda sua obra procura analisar, objetivamente e com rara perspicácia crítica, as causas da crise política, social e literária que sofreu a coletividade romana no decorrer da época imperial. No Dialogus de Oratoribus, Tácito trata o discutido problema das causas do declínio da arte oratória. Aponta três fatôres principais: falta de liberdade devida às mudanças políticas, ausência de ideais e enfraquecimento dos espíritos. Na Germania, o historiador sente uma viva admiração por tudo aquilo que os antigos povos germânicos tinham de nativo, puro, original, simples e selvagem; mas, junto com esta admiração, Tácito expressa o mêdo de que, se os romanos não voltarem à antiga pureza dos costumes, serão inexoràvelmente vencidos pelas fôrças másculas dos germânicos. No Agricola, tecendo o elogio fúnebre de seu sogro e apresentando-o como um verdadeiro romano, de antiga têmpera, que não se dobra em face da tirania, fala do terrorismo cultural da época imperial:

\footnotetext{
"Aruleno Rústico e Herênio Senecião, por terem escrito em honra de Traséia Peto e de Elvídio Prisco, foram condenados a morte; e não sòmente (Domiciano) se enfureceu contra as pessoas dos autores, mas também contra seus escritos, mandando que os monumentos literários daqueles claríssimos engenhos fôssem queimados pùblicamente no Foro. Pensavam que com aquela fogueira pudessem suprimir a voz do povo romano, a liberdade do Senado e a consciência do gênero humano, tendo, além disso, mandado para o exílio os mestres da sabedoria e das artes liberais, para que nada de digno estorvassem sua vida. Na realidade, nós demos uma grande prova de fraqueza; pois, se a época antiga tinha visto a que extremo se pode chegar com a liberdade, nós vimos a que extremo se pode chegar na escravidão, quando por intermédio dos espiões nos foi tirada até a liberdade de falar e de ouvir. E teríamos perdido, junto com a palavra, até a memória, se tivéssemos o poder de esquecer, como temos o poder de calar" (II).
}

Nos Annales e nas Historiae, Tácito faz um retrospecto da época imperial, de Augusto até Nerva, descrevendo os horrores perpetrados pelos déspotas contra homens e coisas do Estado.

E com Tácito se apaga a última grande voz da Romanidade. A Literatura Latina posterior, além de não produzir nenhuma figura expressiva, terá feição mais ocidental do que romana. E' sintomático o fato de que o grande Imperador de Roma, Marco Aurélio, exímio filósofo estóico, não escrevesse suas obras na língua latina, mas em grego: o Helenismo tinha acabado absorvendo completamente a cultura 
e os costumes romanos. E a Igreja, enquanto alargará - através de seu ecumenismo - os limites do mundo cultural romano, dirige as atenções dos povos para uma realidade não mais romana, mas universal e transcendental.

O estudo das relações entre Império e Literatura em Roma, leva-nos às seguintes reflexões. Realmente houve, por parte dos literatos, oposição aos regimes despóticos, ao longo da época imperial. Esta oposição, às vêzes violenta, muitas vêzes fraca e tímida, tinha por objetivo lutar contra a tirania, os excessos do poder e os costumes corruptos da côrte romana, em nome da tradição liberal e democrática. Não pregava a volta às desordens dos últimos anos da República, mas também não queria que o povo romano fôsse vítima dos abusos e da prepotência dos imperadores. Buscava, em suma, aquilo que todos os homens de bem deveriam sempre buscar: o equilíbrio entre a autoridade e a liberdade, entre a ordem e o livre arbítrio, entre o direito do cidadão e a razão de Estado. O grave êrro dos imperadores romanos foi o de não ter sabido aproveitar esta oposição. Existem governos que aceitam a oposição e a utilizam (o govêrno inglês, por exemplo), outros a combatem, como no Império Romano. O fato é que a oposição pode ser aceita e valorizada só por um govêrno legítimo e justo. E tạl não foi, na maioria das vêzes, o govêrno imperial de Roma. Um imperador que mata os principais componentes de sua família, um outro que elege cônsul o seu cavalo, outro que se deixa levar por não sei quais excessos de loucura, êstes tais não podiam, de forma alguma, permitir qualquer tipo de oposição. Quanto mais injusto é o govêrno, tanto mais é levado a repelir a oposição, pois está impossibilitado de ver nela um meio de corrigir eventuais falhas, um elemento crítico construtivo. Só enxerga na oposição um adversário perigoso, um implacável acusador. Daí a necessidade de abafar qualquer grito de revolta, qualquer sintoma de inconformismo. Quase por legítima defesa, então, os imperadores romanos eram obrigados a responder à oposição, concentrada no meio intelectual de Roma, com um terrorismo cultural sem precedentes. Enquanto sustentavam e protegiam os poetas e escritores de côrte, aduladores e servis, verdadeiros espíritos vendidos, de outro lado procuravam sufocar as vozes divergentes e abafar a livre expressão do pensamento. A conseqüência natural de tudo isso foi a decadência da Literatura Latina, que, depois do apogeu alcançado na primeira fase da era de Augusto, só registrou, no longo período imperial, algumas figuras importantes nos breves períodos de afrouxamento da intervenção despótica nas Letras. 